\title{
Inhibition of bacterial activities by solar radiation in nearshore waters and the Gulf of Mexico
}

\author{
Peter Aas ${ }^{1}$, M. Maille Lyons ${ }^{1}$, Ralph Pledger ${ }^{2}$, David L. Mitchell ${ }^{2}$, Wade H. Jeffrey ${ }^{1, *}$ \\ ${ }^{1}$ University of West Florida, Center for Environmental Diagnostics and Bioremediation, 11000 University Parkway, \\ Pensacola, Florida 32514, USA \\ ${ }^{2}$ M. D. Anderson Cancer Center, Smithville, Texas 78957, USA
}

\begin{abstract}
The effects of ultraviolet (UV) radiation on thymidine and leucine incorporation were examined in surface waters from the Gulf of Mexico and Santa Rosa Sound, a mesotrophic estuary in northwest Florida, USA. Whole and $0.8 \mu \mathrm{m}$ filtered surface waters were incubated with ${ }^{3} \mathrm{H}$-thymidine and ${ }^{14} \mathrm{C}$-leucine in UV transparent containers under natural solar radiation. Solar radiation was either not filtered (samples exposed to UV-B, UV-A, and photosynthetically active radiation, PAR), filtered through Mylar 500D (samples exposed to UV-A and PAR), or filtered through Acrylite OP3 (samples exposed only to PAR). In Santa Rosa Sound, thymidine incorporation was inhibited an average of $44 \%$ relative to dark controls when exposed to unfiltered solar radiation. PAR contributed $23 \%$ to the total thymidine inhibition, while UV-A and UV-B contributed $37 \%$ and $39 \%$, respectively, to total inhibition. Leucine incorporation in Santa Rosa Sound was inhibited $29 \%$ by full solar radiation. The majority of the total leucine inhibition was due to UV-B $(83 \%)$, while PAR only treatments showed leucine incorporation rates $10 \%$ higher than dark controls. For the Gulf of Mexico experiments, full solar radiation inhibited thymidine incorporation approximately twice as much as leucine incorporation. However, there were no consistent patterns in differences due to different wavelengths. Both thymidine and leucine incorporation were inhibited to a greater extent in $<0.8 \mu \mathrm{m}$ filtered water samples than in whole water samples, suggesting that the presence of primary producers may mediate the detrimental effects of solar radiation on bacterioplankton. Surface water was also incubated in situ with thymidine at fixed depths in UV transparent and darkened containers at 3 locations in the Gulf of Mexico. Total inhibition was 60 to $70 \%$ at the surface and was evident to $15 \mathrm{~m}$. Comparison with radiometric data and DNA dosimeters indicated that UV-B exerted the greatest effect in the upper $5 \mathrm{~m}$ while below that the inhibition was most likely due to longer wavelengths. Our results suggest that both UV and visible solar radiation can negatively affect bacterial metabolism and failure to take into account the effects of light may result in the overestimation of bacterioplankton production in surface waters
\end{abstract}

KEY WORDS: Ultraviolet radiation - Bacteria Thymidine - Leucine Gulf of Mexico $\cdot$ Global carbon cycle

\section{INTRODUCTION}

Over the past century, anthropogenic inputs to the atmosphere have led to a number of biospherical changes, including increasing levels of atmospheric $\mathrm{CO}_{2}$, changes in the global nitrogen cycle, and decreases in stratospheric ozone concentrations (Vitousek 1994). Stratospheric ozone depletion selectively increases flux of UV-B radiation ( 280 to $320 \mathrm{~nm}$ ) at the

·Addressee for correspondence. E-mail: wjeffrey@uwf.edu earth's surface relative to the amount of UV-A radiation (320 to $400 \mathrm{~nm}$ ) and photosynthetically active radiation (PAR; 400 to $750 \mathrm{~nm}$ ) (Roy et al. 1994). Concern over these global changes has stimulated research on the biological effects of UV radiation (see Karentz et al. 1994 for a review of recent research) and of elevated $\mathrm{CO}_{2}$ (Smith \& Buddemeier 1992), as well as intensified efforts to quantify the global carbon cycle (Cole \& Pace 1995, Jahnke \& Craven 1995).

In recent years, the importance of marine bacterioplankton on the global carbon cycle has been increasingly recognized. In open ocean environments, bacte- 
ria may contribute up to $90 \%$ of cellular DNA (Paul et al. 1985, Coffin et al. 1990) and up to $40 \%$ of planktonic carbon biomass (Cho \& Azam 1990). In addition, bacteria may process up to $50 \%$ of algal primary productivity in marine systems (Azam et al. 1983). Despite the importance of bacteria in recycling carbon in the oceans, little research has been conducted on the effects of atmospheric changes, in particular the effects of $U V$ radiation, on bacterial processes (Bailey et al. 1983, Sieracki \& Sieburth 1986, Herndl et al. 1993, Müller-Niklas et al. 1995, Jeffrey et al. 1996).

Estimates of bacterial production are commonly made using the incorporation of radiolabeled precursor molecules such as ${ }^{3} \mathrm{H}$-thymidine (TdR; Fuhrman \& Azam 1982) and ${ }^{3} \mathrm{H}$ - or ${ }^{14} \mathrm{C}$-leucine (Leu; Chin-Leo \& Kirchman 1988. Simon \& Azam 1989). It has been shown that most incorporated thymidine is present in DNA (Jeffrey et al. 1990, Ducklow et al. 1992), and is therefore used to estimate DNA synthesis. Most newly incorporated leucine is shunted directly into protein synthesis (Simon \& Azam 1989, Kirchman 1993). This type of incorporation assay is most commonly made in darkened containers independent of time of day or depth. While dark incubations eliminate the stimulatory effects of primary production on the incubation, they also eliminate the detrimental effects of solar radiation on bacteria and other components of the ecosystem. In this paper we present the results of a series of experiments wherein we conducted these production estimates in both darkened and UV transparent containers. We present data comparing incubations conducted in the dark to those exposed to full sunlight and to those incubated with selective cutoff filters. We further examined the response of bacterioplankton in whole water and $<0.8 \mu \mathrm{m}$ filtrates. Finally, we present depth profiles of solar inhibition of bacterial activities. The results indicate that failure to take into account the effects of solar radiation may result in inaccurate estimates of bacterioplankton production in near surface waters

\section{MATERIALS AND METHODS}

\section{Determination of relative UV-A, UV-B and PAR} effects: surface incubations. In order to determine the relative effects of UV-B (280 to $320 \mathrm{~nm}$ ), UV-A (320 to $400 \mathrm{~nm})$, and PAR (>400 nm) on thymidine and leucine incorporation, 6 experiments were conducted in Santa Rosa Sound, FL, USA, a mesotrophic estuary. Three experiments were also conducted aboard ship at 3 oligotrophic sites in the Gulf of Mexico (see Table 2 for station locations). Samples from Santa Rosa Sound were collected in a clean bucket while samples from the Gulf of Mexico were collected with a submersible pump from a depth of $<0.2 \mathrm{~m}$. Surface water was dispensed into an acid cleaned $2 \mathrm{l}$ glass bottle and labeled with ${ }^{3} \mathrm{H}-\mathrm{TdR}$ and ${ }^{14} \mathrm{C}$-Leu (New England Nuclear, Wilmington, DE, USA) to a final concentration of 20 and $40 \mathrm{nM}$, respectively (Chin-Leo \& Kirchman 1988), and dispensed into UV transparent containers [i.e. quartz boiling flasks, quartz tubes, or polyethylene bags (WhirlPak ${ }^{\mathrm{IM}}$ )]. The same type of container was used for all samples during any single experiment. Although there has been some concern over possible toxicity of polyethylene bags to primary producers (see Prezelin \& Smith 1993), our preliminary data indicate similar effects of UV radiation on bacterial label incorporation in incubations conducted in different containers (data not shown). The majority of the experiments were conducted using polyethylene bags because they are readily available, inexpensive, and disposabie.

Samples were weighted and incubated in the bottom of 20 l Nalgene opaque white polypropylene containers (autoclave pans) submerged in a flowing seawater bath to maintain ambient temperature. The resulting sample incubation depth was approximately $10 \mathrm{~cm}$. All experiments were conducted on clear days. One container was left open to full solar radiation, one was covered with a sheet of Mylar 500D (DuPont), one was covered with a sheet of Acrylite OP3 (Light Impressions, Rochester, NY, USA), and the incubation containers in the fourth pan were wrapped in aluminum foil and used as a dark control. The screens and incubation containers were scanned using a HewlettPackard Model 8452A spectrophotometer blanked to air Mylar allows passage of wavelengths $>320 \mathrm{~nm}$ (i.e. it blocks penetration of UV-B) while Acrylite OP3 allows passage of wavelengths $>400 \mathrm{~nm}$ (i.e. blocks penetration of both UV.B and UV-A) (Fig. 1).

At approximately 2 to $3 \mathrm{~h}$ intervals, subsamples ( 5 to $10 \mathrm{ml}$ ) were removed for determinations of thymidine and leucine incorporation. Incubations were terminated by the addition of $100 \%$ trichloroacetic acid (TCA) to a final concentration of $5 \%$. Samples were chilled on ice prior to filtering onto $0.2 \mu \mathrm{m}$ polycarbonate filters under low vacuum. Each filter was rinsed with $5 \mathrm{ml}$ ice cold $5 \%$ TCA and $5 \mathrm{ml}$ ice cold $80 \%$ ethanol (Chin-Leo \& Kirchman 1988). Incorporation of radioisotopes was determined by liquid scintillation countiny (rackiard Tri Carb; Dackard Instruments. Downer's Grove, IL, USA).

Size fractionation experiments. On 3 occasions (February 2, 1995, Santa Rosa Sound; June 11 and 13, 1995, Gulf of Mexico) simultaneous incubations were conducted using unfiltered water and the $0.8 \mu \mathrm{m}$ filtrate. Surface water was filtered through a $0.8 \mu \mathrm{m}$ $142 \mathrm{~mm}$ Supor filter (Gelman Sciences) under low vacuum pressure $(<250 \mathrm{~mm} \mathrm{Hg})$ and incubated and processed as above. 


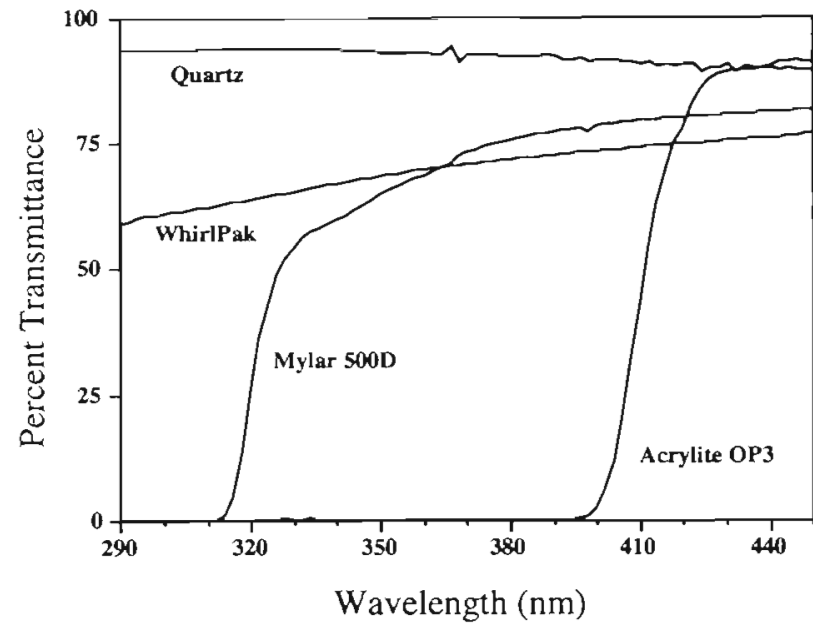

Fig. 1. Spectrophotometric scans of incubation containers used (quartz and WhirlPak bags) as well as screening materials used to filter out UV-B (Mylar 500D) and UV-B and UV-A (Acrylite OP3)

Depth profiles of ${ }^{3} \mathrm{H}$-thymidine incorporation inhibition. Three sites in the Gulf of Mexico were sampled for depth profiles between September 1994 and June 1995. Stn A $\left(29^{\circ} 52^{\prime} \mathrm{N}, 87^{\circ} 07^{\prime} \mathrm{W}\right)$ was sampled on September 8, 1994; $\operatorname{Stn} B\left(28^{\circ} 00^{\prime} \mathrm{N}, 92^{\circ} 30^{\prime} \mathrm{W}\right)$ was sampled on June 10,1995 ; and Stn $C\left(27^{\circ} 31^{\prime} \mathrm{N}, 96^{\circ} 15^{\prime} \mathrm{W}\right)$ was sampled on June 26, 1995.

Surface water samples were collected before sunrise and labeled with ${ }^{3} \mathrm{H}-\mathrm{TdR}$ to a final concentration of $20 \mathrm{nM}$. Quadruplicate $30 \mathrm{ml}$ samples were immediately dispensed into UV transparent containers. Half of the containers were wrapped in aluminum foil as dark controls, while the other half were left uncovered. Samples were attached to a metered line suspended from a buoy at fixed depths between 0.5 and $25 \mathrm{~m}$ and deployed within minutes of sunrise. Near sundown (12 to 14 h later) the buoy was retrieved and the incubations were terminated and processed as described above. Experimental design minimized shading and also prevented unintended exposure to UV radiation.

Dosimeters. Dosimeters are useful as a means to estimate the amount of biologically active UV-B to which samples are exposed (Regan et al. 1992, Jeffrey et al. 1996). At each depth we also attached a dosimeter consisting of a $0.1 \mathrm{mg} \mathrm{ml}^{-1}$ solution of calf thymus DNA (Sigma Chemicals, St. Louis, MO, USA) in a $3 \mathrm{ml}$ quartz tube. The DNA solution from each dosimeter was frozen immediately upon retrieval of the buoy. Radioimmunoassay (RIA) was used to measure cyclobutane pyrimidine dimers (CPDs) caused by UV-B radiation in each of the dosimeter samples (Mitchell et al. 1985, Jeffrey et al. 1996).

Light measurements. Near solar noon of each day, 3 light measurements were made near the deployed buoy using a Biospherical Instruments Model PUV500 (Kirk et al. 1994) broadband profiling radiometer which measures UV radiation at $305,320,340$ and $380 \mathrm{~nm}$ as well as PAR. From these measurements, attenuation coefficients were determined for each wavelength and subsequently used to estimate light penetration in the water column.

Data analysis. The amount of inhibition due to various light treatments was calculated using the following equation: percent inhibition $=[1-($ exposed dpms $/$ dark dpms) $] \times 100$. For each time period, the mean dark value and individual exposed samples were used to calculate average inhibition. Relative effects of full sunlight on TdR incorporation compared to Leu incorporation were determined by dividing $\mathrm{TdR}$ inhibition by Leu inhibition for each time point and will be referred to as the TdR:Leu ratio. Statistical analyses were conducted using the statistics package included with Microsoft Excel 5.0.

\section{RESULTS}

\section{Whole water surface incubations: Santa Rosa Sound}

Data from all experiments conducted in Santa Rosa Sound are presented in Table 1. TdR inhibition in whole water was cumulative during daylight hours and ranged from 12 to $53 \%$. Leu inhibition ranged from 1 to $43 \%$ depending on time of exposure, although cumulative effects were not as apparent. Taking all of the time points together the TdR:Leu ratio was 2.8 , indicating that DNA synthesis was more susceptible than protein synthesis to solar radiation.

The following results refer only to the end-of-day values (i.e. 6.2 to $9.5 \mathrm{~h}$ exposure) for the 6 experiments. There were significant differences in the amount of inhibition in TdR and Leu incorporation due to full solar radiation ( $p<0.0005$; Student's t-test, $n=6$ ) and in the UV-B excluded treatments $(\mathrm{p}<0.05, \mathrm{n}=4)$. Although there were apparent differences in treatments exposed only to PAR, these differences were not significant ( $p>0.05, n=3$ ). Full solar radiation $T d R$ inhibition from the last time point for each experiment averaged $44 \%(\mathrm{SD}=6.7)$ relative to dark controls, whereas Leu inhibition averaged $29 \%(\mathrm{SD}=8.3)$. UV$\mathrm{B}$ contributed $39 \%$ to the total end-of-day TdR inhibition, while UV-A contributed $37 \%$ and PAR $23 \%$. In contrast, UV-B was responsible for $83 \%$ of the total Leu inhibition observed whereas UV-A contributed only $17 \%$. PAR effects on Leu incorporation were variable, but averaged $-10 \%$, e.g. a net stimulus to Leu incorporation relative to dark controls. The enhanced incorporation of leucine may be linked to photosynthesis in the PAR-only treatments. 


\section{Whole water surface incubations: Gulf of Mexico}

Data for all of the Gulf of Mexico samples is presented in Table 2. In November 1994 we only conducted incubations comparing dark and solar exposed samples. Dark TdR incorporation was constant at each time point and averaged $1.6 \times 10^{-11} \mathrm{~mol} \mathrm{l}^{-1} \mathrm{~h}^{-1}$. Inhibition due to solar radiation increased rapidly for the first $5 \mathrm{~h}$ and then increased at a slower rate for the remainder of the day and reached a maximum of $75 \%$ after $11 \mathrm{~h}$ of exposure (Fig. 2). Inhibition of Leu incorporation also increased through the day and reached a maximum of $47 \%$ after $9 \mathrm{~h}$ of exposure. The ratio of TdR inhibition compared to Leu inhibition decreased from 3.14 after 3 h to 1.79 after $11 \mathrm{~h}$, indicating a more rapid response to sunlight of DNA synthesis compared to protein synthesis

For the June experiments from the Gulf of Mexico, the selective wavelength filters were uscd. On June 11, $\mathrm{TdR}$ incorporation was inhibited more than Leu due to full solar radiation, and ranged from 17 to $46 \%$. How-

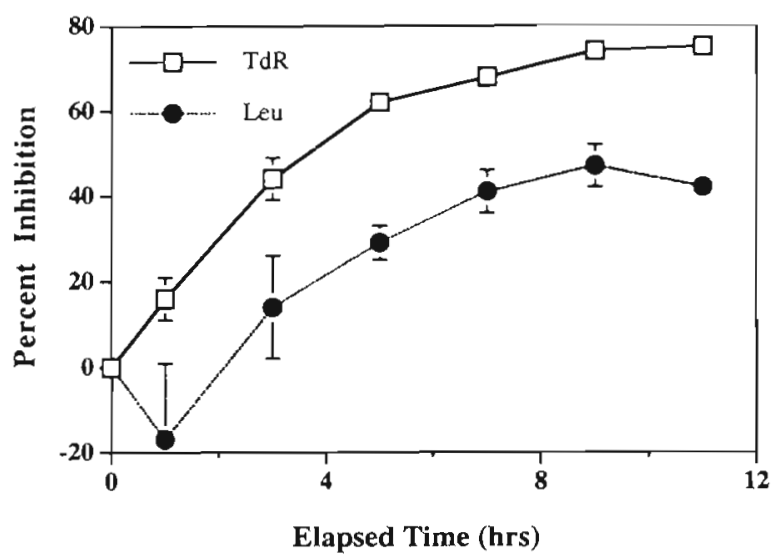

Fig. 2. Effect of full solar radiation on inhibition of thymidine and leucine incorporation in the Gulf of Mexico on November 21, 1994. Data are the mean and standard deviation of 3 measures

ever, the effect in the PAR exposed samples and the PAR + UV-A exposed samples was essentially identi-

Table 1. Summary of solar inhibition (\%) of thymidine and leucine incorporation due to different wavelengths. Data are from dock experiments conducted in Santa Rosa Sound, Florida, USA. Numbers reported are the mean and standard deviation (in parentheses] of replicate measures. For October $n=4$ and November $n=6$. nd: not determined

\begin{tabular}{|c|c|c|c|c|c|c|c|c|c|c|}
\hline $\begin{array}{c}\text { Size } \\
\text { fraction }\end{array}$ & $\begin{array}{l}\text { Time } \\
\text { (h) }\end{array}$ & PAR & $\begin{array}{l}\text { PAR + } \\
\text { UVA }\end{array}$ & $\begin{array}{c}\text { PAR + UVA } \\
+ \text { UVB }\end{array}$ & $\begin{array}{c}\text { Dark TdR } \\
\left(\mathrm{mol} \mathrm{l}^{-1} \mathrm{~h}^{-1}\right)\end{array}$ & PAR & $\begin{array}{l}\text { PAR + } \\
\text { UVA }\end{array}$ & $\begin{array}{c}\text { PAR + UVA } \\
+ \text { UVB }\end{array}$ & $\begin{array}{c}\text { Dark Leu } \\
\left(\mathrm{mol} \mathrm{I}^{-1} \mathrm{~h}^{-1}\right)\end{array}$ & TdR:Leu ${ }^{d}$ \\
\hline \multicolumn{11}{|c|}{ October 24,1994} \\
\hline Whole & 6.7 & nd & $26(7)$ & $38(10)$ & $3.5 \times 10^{-11}$ & nd & $-1(10)$ & $22(21)$ & $8.7 \times 10^{-10}$ & 1.73 \\
\hline \multicolumn{11}{|c|}{ November 2,1994} \\
\hline Whole & 6.2 & nd & nd & $44(5)$ & $2.3 \times 10^{-11}$ & nd & nd & $26(8)$ & $3.6 \times 10^{-10}$ & 1.59 \\
\hline \multicolumn{11}{|c|}{ January 10, 1995} \\
\hline Whole & 7.3 & nd & nd & $52(5)$ & $3.1 \times 10^{-12}$ & nd & nd & $43(8)$ & $4.3 \times 10^{-10}$ & 1.21 \\
\hline \multicolumn{11}{|c|}{ January 20, 1995} \\
\hline \multirow[t]{3}{*}{ Whole } & 2.3 & $16(9)$ & $12(9)$ & $30(13)$ & $2.8 \times 10^{-12}$ & $0(12)$ & $8(9)$ & $20(1.7)$ & $2.1 \times 10^{-10}$ & 1.50 \\
\hline & 6.3 & $15(18)$ & $11(5)$ & $39(2)$ & & $-9(9)$ & $-1(3)$ & $18(8)$ & & 2.17 \\
\hline & 9.3 & $20(16)$ & $24(5)$ & $50(5)$ & & $-13(4)$ & $3(5)$ & $34(5)$ & & 1.47 \\
\hline \multicolumn{11}{|c|}{ February 1, 1995} \\
\hline \multirow[t]{5}{*}{ Whole } & 2 & $1(7)$ & $6(6)$ & $12(2)$ & $2.0 \times 10^{-11}$ & $-9(5)$ & $-2(4)$ & $1(2)$ & $3.2 \times 10^{-10}$ & 12.00 \\
\hline & 4 & $5(5)$ & $27(8)$ & $29(1)$ & & $-7(7)$ & $8(12)$ & $4(2)$ & & 7.25 \\
\hline & 6.2 & $-6(3)$ & $18(2)$ & $28(1)$ & & $-25(3)$ & $-1(2)$ & $9(1)$ & & 3.11 \\
\hline & 8.1 & $-3(2)$ & $24(3)$ & $35(2)$ & & $-28(4)$ & $0(4)$ & $15(2)$ & & 2.33 \\
\hline & 9.5 & $1(4)$ & $27(1)$ & $42(2)$ & & $-27(5)$ & $0(2)$ & $21(3)$ & & 2.00 \\
\hline \multicolumn{11}{|c|}{ February 2, 1995} \\
\hline \multirow[t]{3}{*}{ Whole } & 3.3 & $5(5)$ & $27(2)$ & $32(4)$ & $3.6 \times 10^{-11}$ & $6(3)$ & $15(2)$ & $24(2)$ & $9.8 \times 10^{-9}$ & 1.33 \\
\hline & 5.3 & $0(5)$ & $25(1)$ & $34(7)$ & & $2(5)$ & $12(1)$ & $24(2)$ & & 1.42 \\
\hline & 6.7 & 10 & 29 & 35 & & 8 & 18 & 25 & & 1.40 \\
\hline \multirow[t]{3}{*}{$<0.8 \mu \mathrm{m}$} & 3.3 & $28(10)$ & $29(1)$ & $44(0)$ & $8.5 \times 10^{-12}$ & $13(9)$ & $11(1)$ & $20(2)$ & $2.2 \times 10^{-10}$ & 2.20 \\
\hline & 5.3 & $17(0)$ & $29(2)$ & $49(1)$ & & $-3(2)$ & $11(3)$ & $16(1)$ & & 3.06 \\
\hline & 6.7 & 25 & $26(1)$ & $53(3)$ & & 4 & $6(2)$ & 21. (3) & & 2.52 \\
\hline
\end{tabular}


Table 2. Summary of solar inhibition (\%) of thymidıne and leucine incorporation due to different wavelengths. Data are from shipboard surface incubations conducted in the Gulf of Mexico. Numbers reported are the mean and standard deviation (in parentheses) of replicate measures (June experiments) or triplicate measures (November experiment). nd: not determined; n/a: not applicable

\begin{tabular}{|c|c|c|c|c|c|c|c|c|c|c|}
\hline $\begin{array}{c}\text { Size } \\
\text { fraction }\end{array}$ & $\begin{array}{l}\text { Time } \\
\text { (h) }\end{array}$ & PAR & $\begin{array}{l}\text { PAR + } \\
\text { UVA }\end{array}$ & $\begin{array}{l}\text { PAR + UVA } \\
\text { + UVB }\end{array}$ & $\begin{array}{c}\text { Dark TdR } \\
\left.(\mathrm{mol}]^{1} \mathrm{~h}^{-1}\right)\end{array}$ & PAR & $\begin{array}{l}\text { PAR + } \\
\text { UVA }\end{array}$ & $\begin{array}{c}P A R+\text { UVA } \\
+ \text { UVB }\end{array}$ & 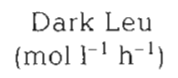 & TdR:Leu ${ }^{d}$ \\
\hline \multicolumn{11}{|c|}{ November $21,1994^{a}$} \\
\hline \multirow[t]{6}{*}{ Whole } & 1 & nd & nd & $16(5)$ & \multirow[t]{6}{*}{$1.6 \times 10^{-11}$} & nd & nd & $-17(18)$ & \multirow[t]{6}{*}{$3.9 \times 10^{-10}$} & $n / a$ \\
\hline & 3 & nd & nd & $44(5)$ & & nd & nd & $14(12)$ & & 3.14 \\
\hline & 5 & nd & nd & $62(2)$ & & nd & nd & $29(4)$ & & 2.14 \\
\hline & 7 & nd & nd & $68(2)$ & & nd & nd & $41(5)$ & & 1.66 \\
\hline & 9 & nd & nd & $74(1)$ & & nd & nd & $47(5)$ & & 1.57 \\
\hline & 11 & nd & nd & $75(1)$ & & nd & nd & $42(1)$ & & 1.79 \\
\hline \multicolumn{11}{|c|}{ June $11,1995^{b}$} \\
\hline \multirow[t]{4}{*}{ Whole } & 1.5 & $20(11)$ & $-1(2)$ & $17(2)$ & \multirow[t]{4}{*}{$1.3 \times 10^{-10}$} & $7(17)$ & $-6(5)$ & $9(0)$ & \multirow[t]{4}{*}{$3.2 \times 10^{-9}$} & 1.89 \\
\hline & 3.8 & $21(0)$ & $14(5)$ & $33(7)$ & & $14(3)$ & $11(8)$ & $29(7)$ & & 1.14 \\
\hline & 7.3 & $17(1)$ & $17(6)$ & $40(2)$ & & $11(5)$ & $8(2)$ & $13(3)$ & & 3.08 \\
\hline & 10.7 & $11(9)$ & $12(3)$ & $46(3)$ & & $3(14)$ & $-7(10)$ & $11(5)$ & & 4.18 \\
\hline \multirow[t]{4}{*}{$<0.8 \mu \mathrm{m}$} & 1.5 & $9(18)$ & $2(2)$ & $10(1)$ & \multirow[t]{4}{*}{$1.9 \times 10^{-11}$} & $7(21)$ & $-6(2)$ & $1(1)$ & \multirow[t]{4}{*}{$1.1 \times 10^{-9}$} & 10.00 \\
\hline & 3.8 & $40(11)$ & $46(1)$ & $59(1)$ & & $12(8)$ & $13(3)$ & $35(3)$ & & 1.68 \\
\hline & 7.3 & $19(0)$ & $36(1)$ & $49(1)$ & & $33(0)$ & $45(3)$ & $64(1)$ & & 0.77 \\
\hline & 10.7 & $30(14)$ & $14(3)$ & $38(11)$ & & $30(14)$ & $26(3)$ & $47(11)$ & & 0.81 \\
\hline \multicolumn{11}{|c|}{ June $13,1995^{c}$} \\
\hline \multirow[t]{4}{*}{ Whole } & 3.2 & $-23(4)$ & $-23(8)$ & $-11(7)$ & \multirow[t]{4}{*}{$1.1 \times 10^{-10}$} & $-25(11)$ & $-20(5)$ & $-13(8)$ & \multirow[t]{4}{*}{$2.3 \times 10^{-9}$} & $\mathrm{n} / \mathrm{a}$ \\
\hline & 6.1 & $-19(0)$ & $5(9)$ & $28(28)$ & & $-2(6)$ & $18(5)$ & $39(21)$ & & 0.72 \\
\hline & 9.3 & $-8(3)$ & $14(1)$ & $46(16)$ & & $13(1)$ & $25(4)$ & $51(16)$ & & 0.90 \\
\hline & 11.3 & $-28(3)$ & $7(14)$ & $29(5)$ & & $-4(4)$ & $14(17)$ & $32(6)$ & & 0.91 \\
\hline \multirow[t]{4}{*}{$<0.8 \mu \mathrm{m}$} & 3.2 & $3(16)$ & $2(4)$ & $23(16)$ & \multirow[t]{4}{*}{$4.6 \times 10^{-11}$} & $4(24)$ & $8(11)$ & $21(24)$ & \multirow[t]{4}{*}{$1.1 \times 10^{-9}$} & 1.09 \\
\hline & 6.1 & $11(2)$ & $30(0)$ & $51(17)$ & & $11(0)$ & $33(3)$ & $52(17)$ & & 0.98 \\
\hline & 9.3 & $11(5)$ & $38(4)$ & $50(3)$ & & $23(2)$ & $44(1)$ & $58(0)$ & & 0.86 \\
\hline & 11.3 & $25(11)$ & $40(2)$ & $56(8)$ & & $39(13)$ & $50(4)$ & $66(7)$ & & 0.85 \\
\hline \multicolumn{11}{|c|}{$28^{\circ} 57.0^{\prime} \mathrm{N}, 89^{\circ} 28.0^{\prime} \mathrm{W}$} \\
\hline \multicolumn{11}{|c|}{$29^{\circ} 01.6^{\prime} \mathrm{N}, 91^{\circ} 40.0^{\prime} \mathrm{W}$} \\
\hline \multicolumn{11}{|c|}{${ }^{\prime} 29^{\circ} 00.1^{\prime} \mathrm{N}, 90^{\circ} 06.1^{\prime} \mathrm{W}$} \\
\hline${ }^{d}$ Ratio of in & ibition & of TdR:Le & m in & $\therefore$. & & ondi to & & & & \\
\hline
\end{tabular}

cal. There were no differences in Leu inhibition due to selective solar filtration at any of the time points on June 11 ( $\mathrm{p}>0.05$; ANOVA).

Unlike the situation on June 11, samples exposed only to PAR on June 13 had higher rates of label incorporation than the dark controls. This may be a function of higher chlorophyll a concentrations in the surface waters on that day $\left(2 \mu \mathrm{g} \mathrm{l}^{-1}\right.$ on June $11,3.5 \mu \mathrm{g} \mathrm{l}^{-1}$ on June 13). Inhibition due to full solar radiation was variable and similar for Leu and TdR.

\section{Whole vs $<0.8 \mu \mathrm{m}$ experiments}

On 1 occasion in Santa Rosa Sound and for both of the June experiments in the Gulf of Mexico we assessed the effects of the presence of phytoplankton on solar effects on bacterial activities.
In all 3 experiments, removal of the $>0.8 \mu \mathrm{m}$ size fraction resulted in lower incorporation rates than in whole water samples for both thymidine and leucine incubated in the dark. In most cases, the filtered samples also experienced greater levels of inhibition. In Santa Rosa Sound, thymidine incorporation was inhibited an average of 18,3 , and $15 \%$ more than whole water in the PAR, PAR + UV-A, and full light treatments, respectively (Fig. 3). Inhibition of Leu incorporation, however, was 4 to $12 \%$ greater in the whole water samples than in the $0.8 \mu \mathrm{m}$ filtered samples (Table 1).

In both of the Gulf of Mexico experiments inhibition of TdR and Leu was generally higher in the filtered samples compared to the whole water samples (Table 2). This was more apparent in the Leu incubations than for TdR on both days. There was a noticeable stimulation due to PAR in the whole water sample 
on June 13. This stimulation, however, was completely eliminated by removing the larger size fraction.

\section{Depth profiles}

The 3 locations at which depth profiles were conducted are characterized by noticeably different light attenuation profiles (Fig. 4). Solar radiation penetrated deepest at $\mathrm{Stn} B$. In contrast, $305 \mathrm{~nm}$ radiation was negligible by $3 \mathrm{~m}$ at Stn $\mathrm{C}$.

Thymidine incorporation was strongly inhibited $(60$ to $70 \%$ ) in near surface samples in our in situ incubations, and decreased with depth. At both Stns A and B, inhibition was negligible by $25 \mathrm{~m}$, while $\mathrm{Stn} C$ showed inhibition only to $10 \mathrm{~m}$ (Fig. 5). The decrease in inhibition was exponential with depth at both Stns A and C, but was more linear at Stn B.

Detectable DNA damage in dosimeters followcd light profile data. The $1 \% 305 \mathrm{~nm}$ penetration depths were approximately 6,10 , and $1.5 \mathrm{~m}$ for Stns $A, B$, and C, respectively (Fig. 3). Similarly, the greatest amount

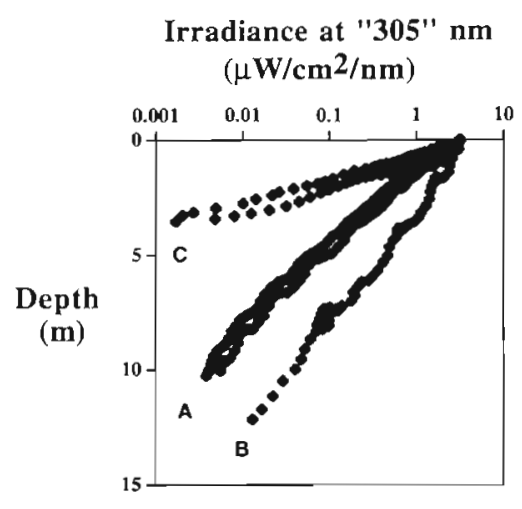

Fig. 4. Penetration of $305 \mathrm{~nm}$ radiation at Stns $\mathrm{A}, \mathrm{B}$, and C in the Gulf of Mexico where depth profile experiments were conducted. See text for station locations

of DNA damage was detected at Stn B, followed by Stn A, with little damage detected at Stn C (Fig. 5). Detectable DNA damage in the dosimeters became negligible at 10,15 , and $3 \mathrm{~m}$ for Stns $\mathrm{A}, \mathrm{B}$, and $\mathrm{C}$, respectively.
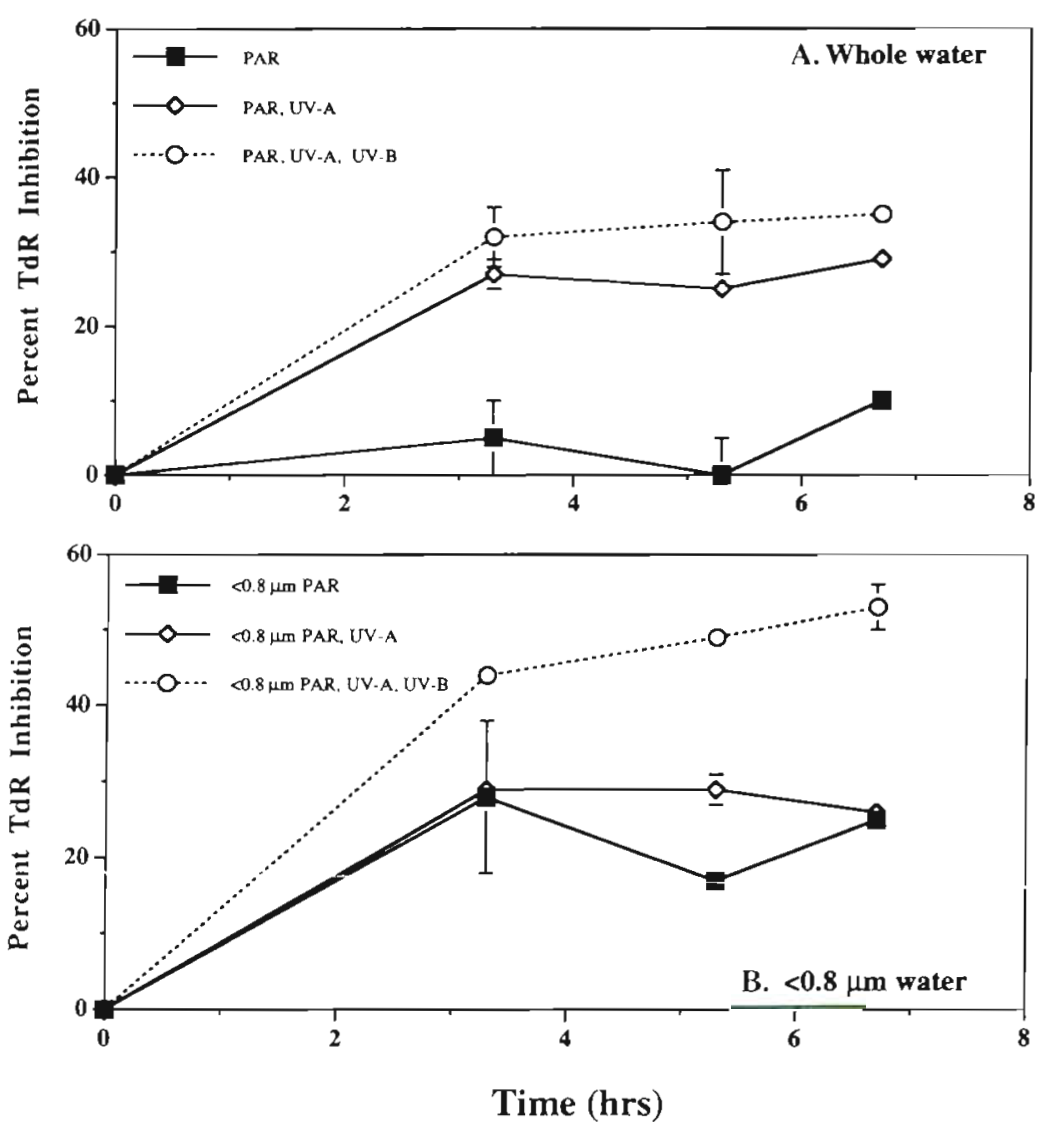

Fig. 3. Inhibition of thymidine incorporation due to PAR, PAR + UV-A, and PAR + UV-A + UV-B. Experiment was conducted in Santa Rosa Sound on February 22, 1995. Results shown for (A) whole water and (B) the $<0.8 \mu \mathrm{m}$ fraction. Data are the mean and standard deviation of 2 measures

\section{DISCUSSION}

Aquatic organisms in surface waters are exposed daily to UV radiation (Karentz et al. 1994). Although stratospheric ozone depletion is likely to exacerbate the effects of UV-B, understanding the biological effects of UV radiation under normal conditions is critical to understanding the effects of these atmospheric changes on aquatic organisms.

The effect of UV radiation on primary producers in aquatic systems has received considerable attention in recent years (Cullen et al. 1992, Cullen \& Neale 1994. Karentz et al. 1994, Lesser et al. 1994). Carbon fixation may be inhibited up to $50 \%$ in surface waters by ambient solar radiation, and the majority of UV inhibition of primary production has been attributed to UV-A (Karentz et al. i994). On a per phiutưii ťasis, UV'-B radiation is more biologically harmful than longer wavelength radiation. Environmentally, however, UV-A is more detrimental overall to primary production due to the higher photon fluence rates in the UV-A range compared to UV-B (Karentz et al. 1994).

The major lethal and mutagenic effects of UV radiation on organisms 


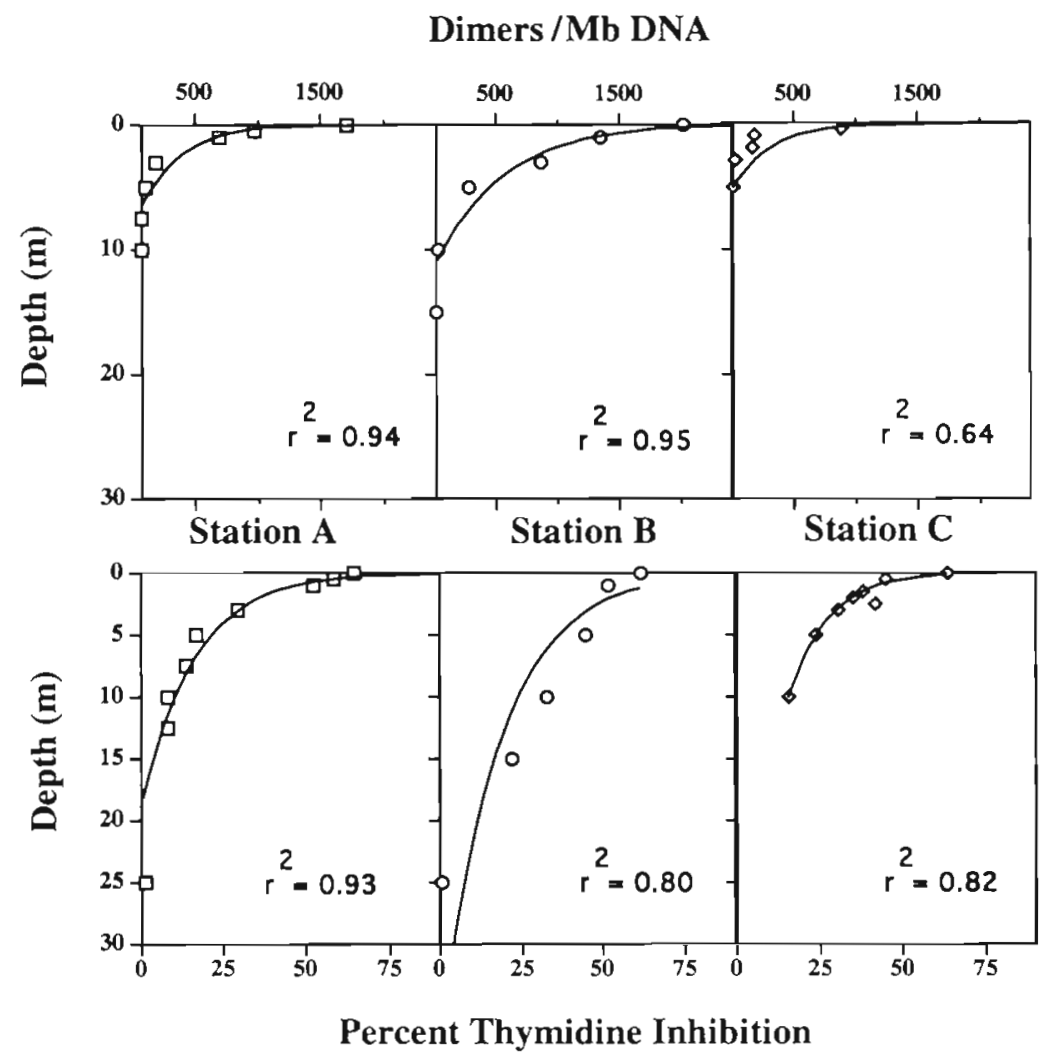

Fig. 5. Thymine dimers measured in dosimeters attached to in situ incubators at Stns $A, B$, and $C$ (top; left to right). Inhibition of thymidine incorporation as a function of depth at Stns $A, B$, and $C$ (bottom; left to right). Lines and $r^{2}$ values are exponential fits of the data

Cells with damaged DNA may continue to produce repair proteins from undamaged portions of the genome while repair is under way. It is apparent, however, that UV radiation disrupts normal growth processes and varying levels of inhibition have been observed. Unfortunately, incorporation of radioisotopes does not allow the separation of label incorporated as a function of semiconservative DNA synthesis and repair synthesis.

UV inhibition is cumulative over the course of the solar day (Fig. 2, Table 1). This cumulative effect is also observed for the accumulation of thymine dimers in bacterioplankton from surface waters in the Gulf of Mexico (Jeffrey et al. 1996). The observed effect is the sum of cellular damage and repair processes DNA repair may be either light dependent via the action of photolyase or light independent via the SOS response (Miller \& Kokjohn 1990, Mitchell \& Karentz 1993). Previous data from the Gulf of Mexico suggest that in surface waters of the Gulf of Mexico damage exceeds repair during the day and dark repair processes predominate overnight. After sunset, bacterioplankton are able to recover from solar UV radiation stress, as evidenced by both

result from damage to DNA. UV-B radiation directly affects DNA by inducing chemical alterations resulting in covalent bonding between adjacent pyrimidine bases [e.g. thymine dimers or (6-4) photoproducts (Mitchell \& Karentz 1993)]. UV-A generally causes indirect damage to DNA through the formation of oxygen and hydroxyl radicals which can form strand breaks, alkali labile sites, and DNA-protein crosslinks (Peak \& Peak 1989).

Thymidine and leucine have been used almost exclusively to estimate bacterial growth in marine systems. Although the thymidine incorporation method has been criticized for a number of reasons (see Robarts \& Zohary 1993), it has been repeatedly shown that most incorporated thymidine is present in DNA (Jeffrey et al. 1990, Ducklow et al. 1992). Most newly incorporated leucine is shunted directly into protein synthesis (Simon \& Azam 1989, Kirchman 1993). UV-B directly damages DNA by inducing bulky adducts (e.g. dimers) that block replication and transcription. Many of the DNA repair mechanisms in bacterial cells rely upon the induction of the SOS response system, including proteins such as recA (Rahman et al. 1995). increases in thymidine incorporation rates and decreases in the number of thymine dimers detected (Jeffrey et al. 1996).

The interactions of primary producers and bacteria also appear to be a critical factor influencing the outcome of UV radiation exposure. Radiotracer bacterial production measures are normally conducted in dark incubations to eliminate the effects of primary production. Indeed, in some of our experiments with whole water we observed higher rates in the PAR exposed samples than in the dark. Removing primary producers from these incubations resulted in greater inhibition of the bacteria by not only UV radiation but PAR as well. It is important to recognize that the measured response of bacteria in whole water incubations represents a combined effect of bacterial inhibition and effects of UV stressed or photo-inhibited phytoplankton. Presumably, removing phytoplankton decreases the nutrient pool available for bacteria, as evidenced by the lower dark incorporation rates in filtered samples. Therefore, understanding the direct effects of UV radiation on bacteria is best accomplished in alga-free incubations, but a true estimate of UV radiation effects 
in the environment requires that both whole and algafree studies be conducted. The interactions between bacteria and phytoplankton are complex and also include interactions with grazers. Our data are preliminary but serve to emphasize that true ecosystem modeling of UV radiation stress requires that all components of the ecosystem be examined simultaneously.

We incubated surface water at various depths in light and dark containers so that the only variable for each depth was light. We estimated the amount of potentially damaging UV-B that reached our incubations using the formation of dimers in DNA dosimeters In all 3 cases, we observed $T d R$ inhibition at deeper depths than biologically active UV-B penetrated, as detected by the dosimeters. Inhibition was generally observed at least twice as deep as dimer formation in the dosimeters. Thus, UV-A may affect bacterial processes at depths well below the attenuation depth of UV-B.

Herndl et al. (1993) estimated the effects of UV radiation on bacterioplankton by using neutral density screening and extrapolated the results to the water column, suggesting that UV-B inhibition should be detectable to $>10 \mathrm{~m}$. Our data indicate that inhibition is indeed measurable to $>10 \mathrm{~m}$, but that UV-A is more likely the causative inhibitor at depths $>10 \mathrm{~m}$, rather than UV-B. Our data demonstrate the difficulty of reproducing natural radiation, its attenuation in the environment and the subsequent biological effects. It is clear that the inhibition of bacterial productivity is influenced by the same factors that influence light attenuation, including both particulate and dissolved compounds. Since different factors will selectively attenuate different wavelengths, it is difficult to predict universal responses, as demonstrated by the differences observed at Stns A, B, and C.

The greatest amount of inhibition occurred in the top few meters of the water column, although biological effects were detected to a depth of $15 \mathrm{~m}$ in our samples (Stn B). These incubations were held at fixed depths and were thus unaffected by any potential mixing. Moderate amounts of mixing have been shown to negate UV-B induced DNA photodamage in water column bacterioplankton (Jeffrey et al. 1996). In calm seas, however, DNA photoproducts from bacterial fractions accumulated to $10 \mathrm{~m}$ at Stn A (Jeffrey et al. 1996).

A previous study in the Adriatic Sea suggested that leucine incorporation is twice as sensitive to UV radiation as is thymidine incorporation in short term incubations (Herndl et al. 1993). Our data, however, indicate that thymidine incorporation is inhibited approximately twice as much as leucine in longer incubations with bacterioplankton from Santa Rosa Sound. In our Gulf of Mexico studies the ratio of the inhibition of TdR:Leu was approximately 1 during the June experi- ments, but ranged from 1.5 to 3.1 during the November experiments. These temporal and regional differences may be the result of different conditions encountered, including bacterial community composition, nutrient status, presence of humic acids, amount of solar radiation, composition and status of the algal community and possibly many other factors. The different observed responses to UV radiation demonstrate the difficulty in predicting universal responses and point to the need for developing biological weighting functions that incorporate differences in ecosystem structure.

Biological weighting functions (BWF) have been investigated in laboratory studies of monocultures of phytoplankton and have been tentatively used to predict environmental response to UV radiation (Cullen et al. 1992, Cullen \& Neale 1994, Lesser et al. 1994). These studies have determined species specific responses to inhibitory effects of narrow ranges of UV radiation (e.g the action spectra) and have incorporated the balance between damage and repair into the model. This model has then been used in conjunction with light penetration data in the water column to predict the response of natural phytoplankton communities to ozone depletion (Cullen et al. 1992).

Our results from Santa Rosa Sound indicate that although full sunlight has less effect on Leu incorporation than on $\mathrm{TdR}$ incorporation, UV-B contributes the majority of the inhibition to Leu incorporation but approximately a third to $\mathrm{TdR}$ inhibition. This is a clear indication that there is a different biological response to different wavelengths of light and suggests the need to develop BWFs for bacterioplankton for both thymidine and leucine incorporation. Estimating a BWF for bacterioplankton is complicated by the relative lack of knowledge concerning the composition of bacterial communities in the environment. Most marine bacteria are morphologically indistinct, and although significant progress has been made in using molecular techniques such as $16 \mathrm{~S}$ rRNA sequencing to characterize communities (Giovannoni et al. 1990, Schmidt et al. 1991, DeLong 1992), most metabolic studies still rely on the 'black box' approach to microbial communities.

It is reasonable to assume that the bacterial communities in Santa Rosa Sound and open waters of the Gulf of Mexico were different, and our results suggest that

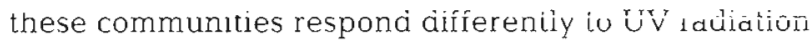
exposure. Similarly, our data suggest that bacterioplankton from Santa Rosa Sound and the Gulf of Mexico showed greater inhibition of TdR than Leu when exposed to full solar radiation. This is in direct opposition to data obtained for bacterioplankton from the Adriatic Sea (Herndl et al. 1993). This may well be due to differences as described above.

The response of bacteria to UV radiation may also vary as a function of the amount and type of dissolved 
organic carbon in the water. During one dock experiment in Santa Rosa Sound when the water contained high humics content, UV radiation exposure resulted in a significant increase in bacterial production (data not shown).

UV radiation may influence bacterial productivity in open oceans. Current concern over depletion of the ozone layer has focused research efforts on the effects of UV-B, but our data indicate that UV-A, which is less affected by ozone depletion (Roy et al. 1994), may have an equal or greater effect. Most microbial ecologists estimate bacterial productivity from thymidine incubations conducted in darkened containers. Regardless of the relative effects of UV-A and UV-B through the water column, it is clear that failure to account for the effects of solar radiation on bacterial production results in overestimation of bacterial carbon production in near surface layers of open ocean waters.

Acknowledgements. This research was supported by U.S. Environmental Protection Agency Cooperative Agreement CR-822020-01 to W.H.J. and D.L.M. through the Gulf Breeze Environmental Research Laboratory. We thank R. B. Coffin, J. D. Pakulski and John Cullen for insightful comments on early drafts of this manuscript. We are grateful to the captains and crews of the OSV 'P. W. Anderson', RV 'Bellowrs', and RV 'Longhorn' for their assistance. Shiptime aboard the RV 'Longhorn' was provided by National Science Foundation grant OCE-9415602 to Curtis Suttie of the University of Texas and we gratefully acknowledge his assistance.

\section{LITERATURE CITED}

Azam F, Fenchel T, Field JG, Gray JS, Meyer-Rell LA, Thingstad $F$ (1983) The ecological role of water-column microbes in the sea. Mar Ecol Prog Ser 10:257-263

Bailey CA, Niehof RA, Tabor PS (1983) lnhibitory effect of solar radiation on amino acid uptake in Chesapeake Bay bacteria. Appl Environ Microbiol 46(1):44-49

Chin-Leo G, Kirchman DL (1988) Estimating bacterial production in marine waters from the simultaneous incorporation of thymidine and leucine. Appl Environ Microbiol $54: 1934-1939$

Cho BC, Azam F (1990) Biogeochemical significance of bacterial biomass in the ocean's euphotic zone. Mar Ecol Prog Ser 63:253-259

Coffin RB, Velinsky D, Devereux R, Price WA, Cifuentes L (1990) Stable carbon isotope analysis of nucleic acids to trace sources of dissolved substrates used by estuarine bacteria. Appl Environ Microbiol 56:2012-2020

Cole JJ, Pace ML (1995) Why measure bacterial production? A reply to the comment by Jahnke and Craven. Limnol Oceanogr 40(2):441-444

Cullen JJ, Neale PJ (1994) Ultraviolet radiation, ozone depletion, and marine photosynthesis. Photosyn Res 39:303-320

Cullen JJ, Neale PJ, Lesser MP (1992) Biological weighting function for the inhibition of phytoplankton photosynthesis by ultraviolet radiation. Science 258:646-650

Delong EF (1992) Archaea in coastal marine environments. Proc Natl Acad Sci USA 89:5685-5689

Ducklow HW, Kirchman DL, Quinby HL (1992) Determination of bacterioplankton growth rates during the North
Atlantic spring phytoplankton bloom: cell growth and macromolecular synthesis in seawater cultures. Microb Ecol 24:125-144

Fuhrman JA, Azam F (1982) Thymidine incorporation as a measure of heterotrophic bacterioplankton production in marine surface waters: evaluation and field results. Mar Biol 66:109-120

Giovannoni SJ, Britschgi TB, Moyer CL, Field KG (1990) Genetic diversity in Sargasso Sea bactenoplankton. Nature 345:60-63

Herndl GJ, Müller-Niklas G, Frick J (1993) Major role of ultraviolet-B in controlling bacterioplankton growth in the surface layer of the ocean. Nature 361:717-719

Jahnke RA, Craven DB (1995) Quantifying the role of heterotrophic bacteria in the carbon cycle: a need for respiration measurements. Limnol Oceanogr 40(2):436-441

Jeffrey WH, Paul JH, Cazares LH, DeFlaun MF, David AW (1990) Correlation of nonspecific macromolecular labeling with environmental parameters during $\left[{ }^{3} \mathrm{H} \mid\right.$ thymidine incorporation in the waters of southwest Florida. Microb Ecol 20:21-35

Jeffrey WH, Pledger RJ, Aas P, Hager S, Coffin RB, Von Haven R, Mitchell DL (1996) Diel and depth profiles of DNA photodamage in bacterioplankton exposed to ambient solar ultraviolet radiation. Mar Ecol Prog Ser 137 : $283-291$

Karentz D, Bothwell ML, Coffin RB, Hanson A, Herndl GJ, Kilham SS, Lesser MP, Lindell M, Moeller RE, Morris DP, Neale PJ, Sanders RW, Weiler CS, Wetzel RG (1994) Impact of UV-B radiation on pelagic freshwater ecosystems: report of working group on bacteria and phytoplankton. Arch Hydrobiol Beih 43:31-69

Kirchman DL (1993) Leucine incorporation as a measure of biomass production by heterotrophic bacteria. In: Kemp PF (ed) Handbook of methods in aquatic microbial ecology. Lewis Publishers, Boca Raton, p 509-512

Kirk JTO, Hargreaves BR, Morris DP, Coffin RB, David B, Frederickson D, Karentz D, Lean DRS, Lesser MP, Madronich S, Morrow JH, Nelson NB, Scully NM (1994) Measurement of UV-B in two freshwater lakes: an instrument intercomparison. Arch Hydrobiol Beih 43: $71-99$

Lesser MP, Cullen JJ, Neale PJ (1994) Carbon uptake ın a marine diatom during acute exposure to ultraviolet $B$ radlation: relative importance of damage and repair. J Phycol 30:183-192

Miller RV, Kokjohn TA (1990) General microbiology of recA: environmental and evolutionary significance. Ann Rev Microbiol 44:365-394

Mitchell DL, Haipek CA, Clarkson JM (1985) (6-4) Photoproducts are removed from the DNA of UV-irradiated mammalian cells more efficiently than cyclobutane pyrimidine dimers. Mutat Res 143:109-112

Mitchell DL, Karentz D (1993) The induction and repair of DNA photodamage in the environment. In: Young AR, Björn L, Moan J, Nultsch W (eds) Environmental UV photobiology. Plenum Press, New York, p 345-377

Müller-Niklas G, Heissenberger A, Puskaric S, Herndl GJ (1995) Ultraviolet-B radiation and bacterial metabolism in coastal waters. Aquat Microb Ecol 9:111-116

Paul JH, Jeffrey WH, DeFlaun MF (1985) Particulate DNA in subtropical oceanic and estuarine planktonic environments. Mar Biol 90:95-101

Peak MJ, Peak JG (1989) Solar-ultraviolet induced damage to DNA. Photodermatology 6:1-15

Prezelin BB, Smith RC (1993) Polyethylene bags and solar ultraviolet radiation-response. Science 259:534-535 
Rahman MS, Bose B, Chatterjee SN (1995) On the induction of protective responses in Salmonella typhimurium strain TA1535/pSK 1002 by UVA (365 nm). Photochem Photobiol $61(5) .471-478$

Regan JD, Carrier WL, Gucinski H, Olla BL, Yoshida H, Fujimura RK, Wicklund RI (1992) DNA as a solar dosimeter in the ocean. Photochem Photobiol 56:35-42

Robarts RS, Zohary T (1993) Fact or fiction - bacterial growth rates and production as determined by [methyl${ }^{3} \mathrm{H}$ ]-thymidine? In: Jones JG (ed) Advances in microbial ecology, Vol 13. Plenum Press, New York, p 371-425

Roy CR, Gies HP, Tomlinson DW, Lugg DL (1994) Effects of ozone depletion on the ultraviolet radiation environment at the Australian stations in Antarctica. In: Weiler CS, Penhale PA (eds) Ultraviolet radiation in Antarctica:

Responsible Subject Editor: J. T Hollibaugh, Tiburon, Caljfornia, USA. measurements and biological effects. Antarct Res Ser 62 : $1-15$

Schmidt TM, DeLong EF, Pace NR (1991) Analysis of a marine picoplankton community by $16 \mathrm{~S}$ rRNA gene cloning and sequencing. J Bacteriol 173(14):4371-4378

Sieracki ME, Sieburth JMCN (1986) Sunlight induced growth delay of planktonic marine bacteria in filtered seawater. Mar Ecol Prog Ser 33:19-27

Simon M, Azam F (1989) Protein content and protein synthesis rates of planktonic marine bacteria. Mar Ecol Prog Ser $51: 201-213$

Smith SV, Buddemeier RW (1992) Global change and coral reef ecosystems. A Rev Ecol Syst 23:89-118

Vitousek PM (1994) Beyond global warming: ecology and global change. Ecology 75(7):1861-1876

Manuscript first received: January 20, 1996

Revised version accepted: August 26, 1996 